\title{
The Complete Mitochondrial Genome of Parasitus Fimetorum (Parasitiformes: Parasitidae) and Phylogenetic Relationship of Parasitiformes
}

\section{Huijuan Yang}

Dali University School of Basic Medicine

WenGe Dong ( $\nabla$ dongwenge2740@sina.com )

Dali University

Ting Chen

Dali University

\section{Research}

Keywords: Parasitidae, Mitochondrial genome, Molecular evolution, Phylogenetic analysis, Gene order

Posted Date: November 16th, 2021

DOI: https://doi.org/10.21203/rs.3.rs-1056107/v1

License: (c) (i) This work is licensed under a Creative Commons Attribution 4.0 International License. Read Full License 


\section{Abstract \\ Background}

The family Parasitidae (Arachnida: Acari) includes 426 species. Up to now, the complete mitochondrial genomes of only one Parasitidae species (Parasitus wangdunqingi) has been sequenced, and it was discovered that the mitochondrial genome of this species have retained the ancestral mitochondrial genome organization of arthropods. The scarcity of available sequence data has greatly impeded evolutionary studies in Acari (mites and ticks). Here, we report the complete mitochondrial genome of Parasitus fimetorum (Family Parasitidae) and provide a comparison to Parasitus wangdunqingi.

\section{Methods}

We use a PCR-based strategy to amplify the mitochondrial genome of Parasitus fimetorum, and these amplicons are sequenced using the Illumina Hiseq X-10 platform. Phylogeny of Parasitiformes mites based on cox 1 gene of 51 species using maximum likelihood (ML) methods.

\section{Result}

The complete mt genome of $P$. fimetorum is a typical circular, double-stranded DNA molecule 14,619 bp in size that contains 13 protein-coding genes, 22 transfer RNA genes, 2 ribosomal RNA genes, and 1 control region. The mitochondrial gene order of $P$. fimetorum was similar to that of the arthropods hypothesized ancestor. Mitochondrial genomes of $P$. fimetorum and $P$. wangdunqingi were compared and analyzed with the following characteristics: (1) both parasitus species evolved independently rather than synergically; (2) the preference of the two mites for codons is different, which may be due to the mutation pressure of certain mites. Phylogenetic analyses based on sequences of the cox1 genes showed that Parasitidae was monophyletic.

\section{Conclusion}

The mitochondrial genomes of Parasitidae mites likely remained the ancestral mt genome organization of arthropods and phylogeny of Parasitiformes mites based on cox 1 gene sequences indicates that different lineages are basically monophyletic, and strong supports the current morphological taxonomy. Among others, this new resource will provided thoroughly and systematically information for further study on the mitogenomes, phylogenetics and taxonomic revision of the mites.

\section{Background}

Parasitidae belong to Acari, Arachnida, Parasitiformes [1]. Literary statistics have shown that 426 species have been registered with 35 genera in the world [2]. Parasitidae mites are common and widely distributed predators in soil ecosystems, prey on mites, eggs and other small arthropods and nematodes in the untimely stage of the soil, most of them live freely or with insects, on rotting hay, compos and feces, and are less parasitic on the surface of mammals [3-5]. Some of the Parasitidae mites are significant for soil vitality, aeration and water retention, decomposition of plant materials, control of microbial biomass and nutrient cycling; other species of the parasitidae mites are important groups of natural enemies for biological control. For instance, gamasid mites can prey on nematodes and bark beetle mites in tunnels, Parasitus coleoptratorum can prey on housefly larvae, Parasitus fimetorum can prey on edible fungus pests, but a few parasitic mites can cause harm to crops, such as Parasitus beta, which can reduce the yield of tobacco seedlings [6-8].

Extensive extranuclear DNA exists in mitochondrial genomes, which exhibits a number of remarkable traits, such like matrilineal inheritance, strong conservation, minimal recombination, rapid gene evolution, among others. These traits distinguish them from other closely comparable prokaryote genomes as well as from eukaryotic genomes [9-11]. Most animal mitochondrial genomes have 14-18kb sized closed twin-stranded loop molecules with 37 genes: two ribosomal RNA (rRNA) genes, $r r n S$ and $r r n L$, have slow evolution rates and are highly conserved genes; 22 transfer RNA (tRNA) genes, are relatively conservative, with a slow evolution rate and low base substitution rate in mtDNA, but the functional regions of tRNA genes are different and conserved, and the 
regions with relatively high variation are T arm and T $\Psi$ C loop; 13 protein-coding genes (PCGs), which protein products are very important for the process of mitochondrial oxidative phosphorylation, and a non-coding region that is mainly thought to play a role in the initiation of DNA transcription or replication (or both) [11-15].

The emergence and maturation of high-throughput sequencing technology in recent years has opened up exciting possibilities for pedigree phylogenetic analysis of lineages that have previously been difficult to study using conventional molecular and morphological approaches. As a consequence, more mitochondrial genomes of arthropods have been sequenced. To date, the mitochondrial genomes of 27 species of Acariformes and 50 species of Parasitiformes have been investigated at home and abroad, and it has been found that the mitochondrial genomes of all species of Acariformes and some species of Parasitiformes have undergone a drastic rearrangement with the mitochondrial genomes of arthropod hypothetical ancestor. A tough task is to appropriately identify the mitochondrial genome due to the presence of gene deletions and rearrangements, and also the existence of contrary base composition, atypical tRNA secondary structure, and a short rRNA sequence [16]. So far, only one complete mitochondrial genome of parasitidae mites (Parasitus wangdunqingi) and the partial $\mathrm{mt}$ gene of other species have been submitted to GenBank. The scarcity of available sequence data has greatly impeded evolutionary studies in Acari (mites and ticks). Here, we sequenced the complete mitochondrial genome of Parasitus fimetorum (Parasitiformes: Parasitidae) collected from Apodemus chevrieri. We use the 5 ' terminal sequence of cox 1 gene to analyse Phylogeny of Parasitiformes mites, which offers integrated scientific data from genetic aspects for the classification and study of the mitochondrial genome of Parasitiformes mites in the future.

\section{Materails And Methods}

\section{Collection of mites}

P. fimetorum were collected from Apodemus chevrieri in Lijiang City, Yunnan Province, China in July, 2019. Mite samples were either used immediately for DNA extraction or were preserved in $100 \%$ ethanol at $-20^{\circ} \mathrm{C}$ prior to DNA extraction. Samples of $P$. fimetorum were also mounted to slides as vouchers, using Hoyer's medium for morphological check with a Zeiss A2 (microphoto camera AxioCam MRc) microscope. The collected specimens and vouchers were deposited at the Institute of Pathogens and Vectors, Dali University, China. Capture of Apodemus chevrieri was approved by health authorities in Yunnan Province, China. Animal capture protocols and procedures were approved by the animal ethics committees at Dali University.

\section{DNA extraction, mt genome amplification and sequencing}

Genomic DNA was extracted from individual mite with DNeasy Blood and Tissue Kit (QIAGEN), following the modified protocol [17]. A 330-bp fragment of $r r n S$ were initially amplified by polymerase chain reaction (PCR) with the primer pairs 12SA and 12SB (see Additional file 1). The pairs of primer target conserved gene sequence motifs that are highly conserved among arthropods. PCR products were directly purified and were sequenced directly using Sanger method at the Thermo Fisher Scientific Genome Sequencing Facility (Guangzhou). Specific primer for $P$. fimetorum, m12SF-m12SR, were designed from rrnS sequence obtained (see Additional file 1). PCR with the specific primer produced about $15 \mathrm{~kb}$ amplicon, which were sequenced from both ends (i.e. paired-end) with lllumina Miseq platform: insert size $400 \mathrm{bp}$, read length $250 \mathrm{bp}$.

Takara Ex Taq was used in the initial short PCRs with the following cycling conditions: $94^{\circ} \mathrm{C}$ for $3 \mathrm{~min} ; 37$ cycles of $94^{\circ} \mathrm{C}$ for $1 \mathrm{~min}$, $54^{\circ} \mathrm{C}$ for $1 \mathrm{~min}, 72^{\circ} \mathrm{C}$ for $1 \mathrm{~min}$; and a final extension of $72^{\circ} \mathrm{C}$ for $10 \mathrm{~min}$. Takara LA Taq was used in the long PCRs with the cycling conditions: $96^{\circ} \mathrm{C}$ for $1 \mathrm{~min} ; 40$ cycles of $96^{\circ} \mathrm{C}$ for $10 \mathrm{sec}, 56-60^{\circ} \mathrm{C}$ for $40 \mathrm{sec}, 68^{\circ} \mathrm{C}$ for $9 \mathrm{~min}$; and a final extension of $68^{\circ} \mathrm{C}$ for 15 min. Positive and negative controls were executed with each PCR experiment. PCR products were checked by agarose gel(1\%)eletrophoresis; the sizes of PCR amplicons were estimated by comparing with DNA markers. PCR products were purified with Wizard SV Gel/PCR clean-up system (Promega). Illumina sequencing was done at the Majorbio Genome Sequencing Facility (Shanghai).

\section{Assembly of Illumina sequence reads and gene identification}

Illumina sequence reads obtained (250 bp each) were assembled into contigs with Geneious 11.1.5 [18]. The assembled parameters were as follows: minimum overlap $150 \mathrm{bp}$, maximum mismatches per read 3\%, minimum overlap identity $98 \%$. The

Page $3 / 20$ 
tRNA genes were identified using tRNAscan-SE [19] and ARWEN [20] or verified by comparison of secondary structures and conserved nucleotide sequences with those of Acari species reported in published literature. Protein-coding genes (PCGs) and were identified by open reading frame (ORF) searches in Geneious using the invertebrate mt genetic code and then by BLAST searches conducted in NCBI [21]. The two rRNA genes, $r r n S$ and $r r n L$, were also identified by BLAST searches of GenBank based on sequence similarity and conserved sequence motifs. The $5^{\prime}$ and $3^{\prime}$ ends of $r r n S$ and $r r n L$ cannot be determined with accuracy. We tentatively annotated the $5^{\prime}$ end of these genes to be immediately after the $3^{\prime}$ end of the upstream gene, and the $3^{\prime}$ end of these genes to be immediately before the downstream gene, leaving no gaps in between. The nucleotide sequences of $\mathrm{mt}$ genomes of $P$. fimetorum have been deposited in GenBank under accession numbers OK572962. Codon usage and Relative Synonymous Codon Usage (RSCU) values were analyzed with MEGA-X [22] and codon W1.4.

\section{Phylogenetic analysis}

Cox1 gene is used for phylogenetic analysis of mitochondrial genome sequence because it contains enough information for phylogenetic comparison [23]. The MEGA-X software was used and the maximum likelihood method was used for Bootstrap analysis. The number of bootstrap replications was 1000 . The nucleotide substitution model was JTT+F+G. Two published Carcinoscorpius rotundicauda and Limulus polyphemus were selected as outgroups in phylogenetic analysis.

\section{Result And Discussion}

\section{General features of P. fimetorum mitogenomes}

The circular mitochondrial genome of $P$. fimetorum (GenBank accession OK572962) is 14,619 base pairs in size, and contains 37 genes, which include 13 protein-coding genes (nad1-nad6, nad4L, cox1-cox3, cob, atp6, atp8), 2 rRNA genes (rrnS and rrnL), and 22 tRNA genes (Fig. 1; Table 1); like the reported mitochondrial genomes of other arthropods. The base composition of this chain is adenine $35.6 \%$, thymine $34.8 \%$, cytosine $18.2 \%$, guanine $11.4 \%$. The overall AT-content of the mt genome of $P$. fimetorum is $70.4 \%$ was near to the average AT-content of Acari mitochondrial genomes (75.34 $\pm 4.78 \%$ ) [24]. Of those, 22 genes, comprising 9 PCG (cox1-3, atp6, atp8, nad2, nad3, nad6, and $\operatorname{cob}$ ) and 13 of the tRNA genes (trnA, $\operatorname{trn} D, \operatorname{trn} E, \operatorname{trn} G, \operatorname{trn} 1, \operatorname{trnK}, \operatorname{trn} M, \operatorname{trnN}, \operatorname{trn} R, \operatorname{trn} S_{1}$, $t_{r n S}, \operatorname{trnT}$ and $\operatorname{trnW}$ ) were coded on the majority stand (J-stand). The other 15 genes were on the minority strand ( $\mathrm{N}$-stand). The mitochondrial genome of $P$. fimetorum is the second sequenced species of Parasitidae, and it shares the same genome structure and content as $P$. wangdunqingi; no gene rearrangement occurs. Gene orders of the mitochondrial genome for two species of mites ( $P$. fimetorum and $P$. wangdunqingi) are identical to those of arthropods hypothetical ancestor, but diverge from those of other Parasitiformes species. While the degree of mitochondrial genome rearrangement in Parasitiformes mites is already quite high in comparison to other metazoans, the degree of mitochondrial gene rearrangement in Acariformes mites is even greater: all 27 Acariformes species mitochondrial genomes measured in previous studies exhibit a high degree of rearrangement. Generally speaking, gene rearrangement occurs seldom in the mitochondrial genomes of the majority of arthropod groupings, and gene content and arrangement are conservative at the lower classification levels (families and genera), even though there are significant changes at the higher classification levels (phylum) [27]. So far, only 23 species of Parasitiformes think that their mitochondrial gene sequence is the same as the arthropods hypothetical ancestor arrangement pattern, of 50 species of mitochondrial genomes that have been measured. These species belong to 6 families: 11 species are located in the Argasidae [25-26], 1 species is seen in the Allothyridae [25], 1 species is placed in the Nuttalliellidae [27], 3 species are known in the Diplogyniidae [28], 1 species are found in the Parasitidae [28], and the remaining 6 species are contained in the Ixodidae [27]. In addition, 27 species from 7 families show varying degrees of rearrangement. There seem to be 16 species of Ixodidae [29], 1 species of Varroidae [30], 3 species of Phytoseiidae [28], with the rate of rearrangement of the mitochondrial genome being the highest studied, 2 species of Laelapidae [28], 3 species of Macrochelidae [28], 1 species of Blattisociidae [28], and 1 species of Ologamasidae [28]. 
Table 1

List of annotated mitochondrial genome of Parasitus fimetorum

\begin{tabular}{|c|c|c|c|c|c|c|}
\hline Genes & Strand & Size & Intergenic length & Start codon & Stop codon & Anticodon \\
\hline $\operatorname{cox} 1$ & $J$ & 1500 & 3 & ATT & TAA & \\
\hline $\operatorname{cox} 2$ & $J$ & 679 & 0 & ATG & $\mathrm{T}$ & \\
\hline $\operatorname{trnK}$ & $\mathrm{J}$ & 68 & 2 & & & CUU \\
\hline $\operatorname{trn} D$ & $J$ & 62 & 0 & & & GUC \\
\hline atp8 & $J$ & 162 & -4 & ATT & TAA & \\
\hline atp6 & $J$ & 666 & 3 & ATA & TAA & \\
\hline $\operatorname{cox} 3$ & $J$ & 778 & 0 & ATG & $\mathrm{T}$ & \\
\hline $\operatorname{trn} G$ & $\mathrm{~J}$ & 62 & 0 & & & UCC \\
\hline nad3 & $J$ & 339 & -2 & ATT & TAG & \\
\hline $\operatorname{trn} A$ & $\mathrm{~J}$ & 63 & 0 & & & UGC \\
\hline $\operatorname{trnR}$ & $\mathrm{J}$ & 61 & 3 & & & UCG \\
\hline $\operatorname{trn} N$ & $J$ & 67 & -1 & & & GUU \\
\hline $\operatorname{trn} S_{1}$ & $\mathrm{~J}$ & 59 & 2 & & & GCU \\
\hline $\operatorname{trn} E$ & $J$ & 65 & -2 & & & UUC \\
\hline $\operatorname{trnF}$ & $\mathrm{N}$ & 63 & 0 & & & GAA \\
\hline nad5 & $\mathrm{N}$ & 1681 & 0 & GTG & $\mathrm{T}$ & \\
\hline $\operatorname{trnH}$ & $\mathrm{N}$ & 62 & 0 & & & GUG \\
\hline nad4 & $\mathrm{N}$ & 1302 & 37 & ATA & TAA & \\
\hline nad4L & $\mathrm{N}$ & 276 & 17 & ATG & TAA & \\
\hline $\operatorname{trn} T$ & $\mathrm{~J}$ & 62 & -1 & & & UGU \\
\hline $\operatorname{trn} P$ & $\mathrm{~N}$ & 64 & 1 & & & UGG \\
\hline nad6 & $\mathrm{J}$ & 435 & -1 & ATT & TAA & \\
\hline$c o b$ & $J$ & 1114 & 0 & ATG & $\mathrm{T}$ & \\
\hline $\operatorname{trn} S_{2}$ & $J$ & 62 & 22 & & & UGA \\
\hline nad1 & $\mathrm{N}$ & 909 & 0 & GTG & TAA & \\
\hline $\operatorname{trn} L_{2}$ & $\mathrm{~N}$ & 62 & 1 & & & UAA \\
\hline $\operatorname{trn} L_{1}$ & $\mathrm{~N}$ & 64 & 0 & & & UAG \\
\hline$r r n L$ & $\mathrm{~N}$ & 1194 & 0 & & & \\
\hline $\operatorname{trn} V$ & $\mathrm{~N}$ & 63 & 0 & & & UAC \\
\hline$r r n S$ & $\mathrm{~N}$ & 707 & 0 & & & \\
\hline NCR\#2 & & 406 & 0 & & & \\
\hline trnl & $\mathrm{J}$ & 64 & -3 & & & GAU \\
\hline $\operatorname{trn} Q$ & $\mathrm{~N}$ & 65 & 20 & & & UUG \\
\hline
\end{tabular}




\begin{tabular}{|lllllll|}
\hline Genes & Strand & Size & Intergenic length & Start codon & Stop codon & Anticodon \\
\hline $\operatorname{trn} M$ & $\mathrm{~J}$ & 64 & 0 & & & CAU \\
\hline nad2 & $\mathrm{J}$ & 963 & -2 & ATT & TAA & \\
$\operatorname{trn} W$ & $\mathrm{~J}$ & 63 & -8 & & UCA \\
$\operatorname{trn} C$ & $\mathrm{~N}$ & 62 & 0 & & GCA \\
$\operatorname{trn} Y$ & $\mathrm{~N}$ & 63 & 31 & & GUA \\
\hline
\end{tabular}


Table 2

The range of intergenic and overlapping regions of 51 species

\begin{tabular}{|c|c|c|c|c|c|c|}
\hline Order & Family & Species & $\begin{array}{l}\text { Accession } \\
\text { number }\end{array}$ & $\begin{array}{l}\text { Interval } \\
\text { range }\end{array}$ & $\begin{array}{l}\text { Overlap } \\
\text { range }\end{array}$ & $\begin{array}{l}\text { Control } \\
\text { region }\end{array}$ \\
\hline Holothyrida & Allothyridae & Allothyrus sp. & KC769586 & $1-20$ & $1-8$ & 348 \\
\hline \multirow[t]{31}{*}{ Ixodida } & Argasidae & Antricola mexicanus & KC769591 & $1-15$ & $1-8$ & 335 \\
\hline & & Argas africolumbae & JQ665720 & $1-8$ & $1-64$ & 343 \\
\hline & & Argas lagenoplastis & KC769587 & $1-20$ & $1-29$ & 343 \\
\hline & & Argas miniatus & KC769590 & $1-18$ & $1-9$ & 346 \\
\hline & & Argas sp. & KC769588 & $1-18$ & $1-8$ & 344 \\
\hline & & Carios capensis & AB075953 & $1-7$ & $1-57$ & 342 \\
\hline & & Ornithodoros brasiliensis & KC769593 & $1-22$ & $1-9$ & 343 \\
\hline & & Ornithodoros moubata & AB073679 & $1-8$ & $1-47$ & 342 \\
\hline & & Ornithodoros porcinus & AB105451 & $1-8$ & $1-100$ & 338 \\
\hline & & Ornithodoros rostratus & KC769592 & $1-15$ & $1-8$ & 340 \\
\hline & & Otobius megnini & KC769589 & $1-15$ & $1-8$ & 340 \\
\hline & Ixodidae & Amblyomma cajennense & JX573118 & $1-16$ & $1-24$ & 304304 \\
\hline & & Robertsicus elaphensi & JN863729 & $1-14$ & $1-15$ & 308286 \\
\hline & & Aponomma fimbriatum & JN863730 & $1-11$ & $1-66$ & 307269 \\
\hline & & $\begin{array}{l}\text { Archaeocroton } \\
\text { sphenodonti }\end{array}$ & JN863731 & $1-13$ & $1-48$ & 317311 \\
\hline & & Amblyomma triguttatum & AB113317 & $1-14$ & $1-67$ & 307307 \\
\hline & & Bothriocroton concolor & JN863727 & $1-16$ & $1-23$ & 303298 \\
\hline & & Bothriocroton undatum & JN863728 & $1-9$ & $1-31$ & 302302 \\
\hline & & Dermacentor nitens & KC503258 & $1-324$ & $1-11$ & 311306 \\
\hline & & Haemaphysalis flava & AB075954 & $1-12$ & $1-14$ & 310310 \\
\hline & & $\begin{array}{l}\text { Haemaphysalis } \\
\text { formosensis }\end{array}$ & JX573135 & $1-11$ & $1-20$ & 316310 \\
\hline & & Haemaphysalis inermis & JX573136 & $1-144$ & $1-8$ & 320318 \\
\hline & & Ixodes hexagonus & AF081828 & $1-16$ & $1-59$ & 359 \\
\hline & & Ixodes holocyclus & AB075955 & $1-15$ & $1-10$ & 450 \\
\hline & & Ixodes pavlovskyi & KJ000060 & $1-14$ & $1-57$ & 354 \\
\hline & & Ixodes persulcatus & AB073725 & $1-12$ & $1-59$ & 352 \\
\hline & & Ixodes ricinus & JN248424 & $1-354$ & $1-19$ & 354 \\
\hline & & Ixodes uriae & AB087746 & $1-12$ & $1-7$ & 476388 \\
\hline & & Rhipicephalus australis & KC503255 & $1-27$ & $1-11$ & 310305 \\
\hline & & Rhipicephalus geigyi & KC503263 & $1-117$ & $1-13$ & 306302 \\
\hline & & Rhipicephalus microplus & KC503260 & $1-11$ & $1-13$ & 310307 \\
\hline
\end{tabular}




\begin{tabular}{|c|c|c|c|c|c|c|}
\hline Order & Family & Species & $\begin{array}{l}\text { Accession } \\
\text { number }\end{array}$ & $\begin{array}{l}\text { Interval } \\
\text { range }\end{array}$ & $\begin{array}{l}\text { Overlap } \\
\text { range }\end{array}$ & $\begin{array}{l}\text { Control } \\
\text { region }\end{array}$ \\
\hline & & Rhipicephalus sanguineus & AF081829 & $1-24$ & $1-13$ & 305303 \\
\hline & & Rhipicephalus simus & KJ739594 & $1-60$ & $1-13$ & 309 \\
\hline & Nuttalliellidae & Nuttalliella namaqua & NC019663 & $1-5$ & $1-11$ & 339 \\
\hline \multirow[t]{16}{*}{ Mesostigmata } & Varroidae & Varroa destructor & AJ493124 & $1-360$ & $1-62$ & 2174 \\
\hline & Ologamasidae & Stylochyrus rarior & GQ927176 & $1-16$ & $1-13$ & 471399 \\
\hline & Parasitidae & Parasitus wandunqingi & MK270528 & $1-31$ & $1-8$ & 413 \\
\hline & & Parasitus fimetorum & OK572962 & $1-37$ & $1-8$ & 406 \\
\hline & Blattisociidae & Blattisocius tarsalis & MK270529 & $1-11$ & $1-4$ & 425513 \\
\hline & Laelapidae & Coleolaelaps c.f. liui & MK270524 & $1-56$ & $1-32$ & 312326 \\
\hline & & Hypoaspis linteyini & MK270530 & $1-30$ & $1-11$ & 398319 \\
\hline & Phytoseiidae & Phytoseiulus persimilis & GQ222414 & $1-39$ & $1-11$ & $\begin{array}{l}555578112 \\
568\end{array}$ \\
\hline & & Metaseiulus occidentalis & EF221760 & $1-129$ & $1-57$ & $\begin{array}{l}311310311 \\
311\end{array}$ \\
\hline & & Euseius nicholsi & KM999989 & $1-335$ & $1-11$ & 386279 \\
\hline & Diplogyniidae & $\begin{array}{l}\text { Quadristernoseta c.f. } \\
\text { intermedia }\end{array}$ & MK270521 & $1-31$ & $1-9$ & 437 \\
\hline & & $\begin{array}{l}\text { Quadristernoseta c.f. } \\
\text { longigynium }\end{array}$ & MK270522 & $1-31$ & $1-8$ & 479 \\
\hline & & Microdiplogynium sp. & MK270523 & $1-31$ & $1-8$ & 432 \\
\hline & Machochelidae & Macrocheles glaber & MK270525 & $1-40$ & $1-7$ & 400 \\
\hline & & $\begin{array}{l}\text { Macrocheles } \\
\text { muscaedomesticae }\end{array}$ & MK270526 & $1-32$ & $1-2$ & 368 \\
\hline & & Macrocheles nataliae & MK270527 & $1-38$ & $1-131$ & 496425 \\
\hline
\end{tabular}

Mitochondrial gene order changes not only between families (Varroidae, Phytoseiidae, Laelapidae, Macrochelidae, Blattisociidae, and Ologamasidae), but also between different genera within the same family (Coleolaelaps c.f. liui (Laelapidae: Coleolaelaps) and Hypoaspis linteyini (Laelapidae: Hypoaspis); Metaseiulus occidentalis (Phytoseiidae: Typhlodrominae) and Phytoseiulus persimilis (Phytoseiidae: Amblyseiinae)). Furthermore, the mite mitochondrial gene rearrangements of 27 species in 7 families display the following characteristics: the rearrangement rate is high, the degree of rearrangement varies among families, and the rearrangement is primarily tRNA rearrangement in nature. Each sequenced mite had at least two tRNA translocations, and the cox2$\operatorname{trn} D$, nad $4 L$-trnT and control areas, as well as the nad2 gene junction, were all frequent translocations of tRNA rearrangements in the mite mitochondrial genomes.

\section{Gene spacer and gene overlap}

Gene overlap region is a section of the mitochondrial genome where the same nucleic acid sequence is involved in the coding of multiple genes. Intergenic region is a portion of the mitochondrial genome that contains non-coding sequences between the coding genes, and its size varies substantially. Gene overlaps were revealed th the 9 gene junctions of $P$. fimetorum, involving a total of 24 bp. The overlap between trnW and trnC is the longest $(7 \mathrm{bp})$. In addition to the large non-coding regions, the mitochondrial genome of $P$. fimetorum encloses several small non-coding intergenic regions, most of which are distributed at 12 gene junctions and range in diameter from 1 to $37 \mathrm{bp}$. The nad 4 and nad $4 L$ genes contain the intergenic region with the longest size. The gene interval and gene overlap range of 51 species sequenced from the Parasitiformes were summarized in this paper (Table 2). The longest spacer 
(360bp) is found in Varroa destructor (Varroidae), and the overlap area is found in Macrocheles nataliae (Machochelidae), which also has the highest overlap area (131bp). There is gene spacer and overlap in each mitochondrial genome of the Parasitiformes, and the positions of the spacer and overlap vary substantially between families and between genera. In most circumstances, the development of gene spacers promotes biological evolution because spacer genes allow for the storage of additional genetic information as well as an increase in the likelihood of mutation.

\section{Analysis of protein coding genes and use of codons in mitochondrial genome}

The occurrence of the start and stop codons, as well as the sequence similarity with other complete Parasitiformes mtDNA sequences, confirm the existence of a protein coding gene (PCG). The total length of the 13 PCGs is $10,804 \mathrm{bp}$ (just the sum of the lengths of 13 protein-coding genes was computed, the gene spacer was not included), accounting for $73.90 \%$ of the entire length of $P$. fimetorum mitochondrial genome. PCGs have an overall A + T content of $69.4 \%$, with a range of $64.3 \%$ (cox3) to $75.9 \%$ (atp8) of the total. The traditional ATN codons were used as start codons in most protein-coding genes, and the use of these start codons appeared to follow the patterns that are conserved in the mitochondrial genomes like most Acari species and even some arthropods [16]: five (cox1, atp8, nad2, nad3 and nad6) with ATT, four (cox2, cox3, cob, and nad4L) with ATG, two (atp6 and nad4) with ATA, whereas has two (nad1 and nad5) appear to start with GTG (Table 1), which is a rare start codon for animal mitochondrial. Eight PCGs terminate with the conventional stop codons TAA (cox1, nad1, nad2, nad4, nad6, nad4L, atp6 and atp8), one PCG terminate with the conventional stop codons TAG (nad3), whereas the remaining four genes (cox2, cox3, cob and nad5) ended at a single $\mathrm{T}$ residue. A typical occurrence in metazoan mitochondrial genomes is the occurrence of an incomplete stop codon, and these incomplete stop codons are thought to be performed through post-transcriptional polyadenylation [31-33].

In genetic information is available biological function, codons are critical as they serve as a link between genes and proteins. Protein coding genes contain a total of 64 triplet codons in their coding sequences. Synonym codons are used to various codons that encode the same amino acid. The amino acids encoded by these 64 triplet codons are divided into 20 separate categories [34-35]. Using MEGA-X and codon W tools, the amino acid usage and codon usage frequency of 13 protein coding genes sequences from two species of Parasitidae were assessed and compared in this study. The mitochondrial PCGs of two parasitic mites was subjected to a relative synonymous codon usage (RSCU) analysis, which suggested that 62 amino-acid encoding codons identified in the mitochondrial PCGs of two parasitic mites are also discovered in other invertebrates [36]. Among the amino acids found in the mitochondrial genomic PCGs of $P$. fimetorum and $P$. wangdunqingi, the amino acids leucine (12.880 14.361\%), serine (9.444 9.530\%), and isoleucine (8.260 9.083\%) are the most frequently encountered, while cysteine $(0.840 \sim 0.972 \%)$ is the least frequently encountered. The atp 8 gene, for illustration, was appearance in $P$. fimetorum, which has the fewest types of amino acids and does not contain any of the essential amino acids glycine $\llbracket$ arginine and aspartic acid, whereas the nad4 $L$ gene was discovered in $P$. wangdunqingi, which also has the fewest types of amino acids, does not contain any of the essential amino acids proline $\llbracket$ glutamine】threonine and tryptophan. The amino acid profile of the proteins encoded by $P$. fimetorum and $P$. wangdunqingi are biased by the fact that the two parasite mites have different bases in the two chains. Table 3 depicts the codon use of the 13 protein-coding genes sequences. P. fimetorum has a higher relative codon usage than 1 for 32 codons. Codons with higher relative codon usage than 1 are referred to as preferred codons of mtDNA-encoded protein genes. The preference codon of protein genes encoded by mtDNA in $P$. fimetorum is higher than that of $P$. wangdunqingi. Only 29 codons of $P$. wangdunqingi had a relative usage rate higher than 1 . Two mites ( $P$. fimetorum and $P$. wangdunqingi) prefers to use U-baseterminated codons ( $P$. fimetorum exception of AGUGGAU and CGU, $P$. wangdunqingi exception of CGU, the other are preferred codons), which are followed by A-base-terminated codons (especially $P$. fimetorum AGA and $P$. wangdunqingi UUA, whose relative codon usage is 2.06 and 2.45, respectively). To some extent, $P$. fimetorum should avoid using G-base-terminated codons (other than AGG, AUG and UGG, and every other relative codon usage is less than 1), and $P$. wangdunqingi should avoid using C-baseterminated codons as much as possible. From an evolutionary perspective, the codon usage of the closely related species seems to be more similar than that of the unrelated species. It is estimated that the proportion of U3s in the $P$. fimetorum and $P$. wangdunqingi mtDNA coding protein gene is higher than the proportion of A3s, C3s, and G3s (Table 4). Kimura (1981) genuinely think that codon usage preference is related to GC content, and that codon usage preference related to GC content is affected by mutation pressure, whereas codon usage preference unrelated to GC content is affected by natural selection pressure [37-39]. By comparing the GC and third GC codon content (GC3s) with $P$. fimetorum and $P$. wangdunqingi protein coding genes, the GC and

Page $9 / 20$ 
GC3s contents of $P$. fimetorum were observed to be greater than the $P$. wangdunqingi. Mutation pressure may cause the difference in codon usage preference between $P$. fimetorum and $P$. wangdunqingi. 
Table 3

RSCU of preferable codons of mtDNA protein coding sequences in P. fimetorum and $P$. wangdunqingi

\begin{tabular}{|c|c|c|c|c|c|c|c|c|c|c|c|}
\hline \multicolumn{2}{|c|}{ Amino acid Codon } & \multicolumn{2}{|c|}{ P.fimetorum } & \multicolumn{2}{|c|}{ P. wangdunqingi } & \multicolumn{2}{|c|}{ Amino acid Codon } & \multicolumn{2}{|c|}{ P. fimetorum } & \multicolumn{2}{|c|}{ P. wangdunqingi } \\
\hline & & Number & RSCU & Number & RSCU & & & Number & RSCU & Number & RSCU \\
\hline \multirow[t]{2}{*}{ Phenylalanine } & UUU & 177 & 1.48 & 271 & 1.63 & \multirow[t]{4}{*}{ Alanine } & GCU & 41 & 1.69 & 43 & 2.05 \\
\hline & UUC & 63 & 0.52 & 61 & 0.37 & & GCC & 32 & 1.32 & 11 & 0.52 \\
\hline \multirow[t]{6}{*}{ Leucine } & UUA & 121 & 2.01 & 210 & 2.45 & & GCA & 21 & 0.87 & 26 & 1.24 \\
\hline & UUG & 49 & 0.81 & 69 & 0.80 & & GCG & 3 & 0.12 & 4 & 0.19 \\
\hline & CUU & 75 & 1.25 & 104 & 1.21 & \multirow[t]{2}{*}{ Histidine } & CAU & 58 & 1.26 & 49 & 1.18 \\
\hline & CUC & 28 & 0.47 & 31 & 0.36 & & CAC & 34 & 0.74 & 34 & 0.82 \\
\hline & CUA & 66 & 1.10 & 69 & 0.80 & \multirow[t]{2}{*}{ Glutamine } & CAA & 74 & 1.68 & 40 & 1.21 \\
\hline & CUG & 22 & 0.37 & 32 & 0.37 & & CAG & 14 & 0.32 & 26 & 0.79 \\
\hline \multirow[t]{3}{*}{ Isoleucine } & AUU & 161 & 1.36 & 207 & 1.54 & \multirow{2}{*}{$\begin{array}{l}\text { L- } \\
\text { Asparagine }\end{array}$} & AAU & 166 & 1.26 & 113 & 1.48 \\
\hline & AUC & 44 & 0.37 & 48 & 0.36 & & AAC & 98 & 0.74 & 40 & 0.52 \\
\hline & AUA & 150 & 1.27 & 149 & 1.11 & \multirow[t]{2}{*}{ lysine } & AAA & 182 & 1.58 & 74 & 1.24 \\
\hline Methionine & AUG & 35 & 1.00 & 49 & 1.00 & & AAG & 49 & 0.42 & 45 & 0.76 \\
\hline \multirow[t]{4}{*}{ Valine } & GUU & 37 & 1.45 & 63 & 1.45 & \multirow{2}{*}{$\begin{array}{l}\text { Aspartic } \\
\text { acid }\end{array}$} & GAU & 17 & 0.74 & 48 & 1.39 \\
\hline & GUC & 21 & 0.82 & 11 & 0.25 & & GAC & 29 & 1.26 & 21 & 0.61 \\
\hline & GUA & 35 & 1.37 & 64 & 1.47 & \multirow{2}{*}{$\begin{array}{l}\text { Glutamic } \\
\text { acid }\end{array}$} & GAA & 37 & 1.51 & 53 & 1.29 \\
\hline & GUG & 9 & 0.35 & 36 & 0.83 & & GAG & 12 & 0.49 & 29 & 0.71 \\
\hline \multirow[t]{6}{*}{ Serine } & UCU & 100 & 1.82 & 82 & 1.88 & \multirow[t]{2}{*}{ Cysteine } & UGU & 50 & 1.28 & 66 & 1.52 \\
\hline & UCC & 46 & 0.84 & 34 & 0.78 & & UGC & 28 & 0.72 & 21 & 0.48 \\
\hline & UCA & 65 & 1.19 & 47 & 1.08 & \multirow[t]{2}{*}{ Tryptophan } & UGG & 27 & 1.00 & 30 & 1.00 \\
\hline & UCG & 7 & 0.13 & 10 & 0.23 & & UGA & 51 & 0.55 & 59 & 0.57 \\
\hline & AGU & 47 & 0.86 & 59 & 1.35 & \multirow[t]{6}{*}{ Arginine } & CGU & 15 & 0.58 & 20 & 0.83 \\
\hline & AGC & 64 & 1.17 & 30 & 0.69 & & CGC & 13 & 0.51 & 8 & 0.33 \\
\hline \multirow[t]{4}{*}{ Proline } & $\mathrm{CCU}$ & 52 & 1.17 & 43 & 1.74 & & CGA & 26 & 1.01 & 20 & 0.83 \\
\hline & $\mathrm{CCC}$ & 65 & 1.46 & 28 & 1.13 & & CGG & 12 & 0.47 & 10 & 0.42 \\
\hline & CCA & 51 & 1.15 & 23 & 0.93 & & AGA & 53 & 2.06 & 41 & 1.71 \\
\hline & CCG & 10 & 0.22 & 5 & 0.20 & & AGG & 35 & 1.36 & 45 & 1.88 \\
\hline \multirow[t]{4}{*}{ Threonine } & $\mathrm{ACU}$ & 92 & 1.63 & 65 & 1.70 & \multirow[t]{4}{*}{ Glycine } & GGU & 27 & 1.23 & 52 & 1.78 \\
\hline & ACC & 54 & 0.96 & 28 & 0.73 & & GGC & 18 & 0.82 & 7 & 0.24 \\
\hline & ACA & 59 & 1.04 & 50 & 1.31 & & GGA & 26 & 1.18 & 37 & 1.26 \\
\hline & ACG & 21 & 0.37 & 10 & 0.26 & & GGG & 17 & 0.77 & 21 & 0.72 \\
\hline \multirow[t]{2}{*}{ Tyrosine } & UAU & 202 & 1.46 & 209 & 1.53 & \multirow[t]{2}{*}{ Stop codon } & UAA & 176 & 1.91 & 155 & 1.49 \\
\hline & UAC & 75 & 0.54 & 65 & 0.47 & & UAG & 49 & 0.53 & 99 & 0.95 \\
\hline
\end{tabular}


Table 4

Codon A3s, U3s, G3s, C3s, GC3s, GC content of protein gene encoded by two mitochondrial genomes of Parasitidae. A3s, U3s, G3s and C3s show the codon contents ending with four bases A, U, G and C, respectively; GC3s represents GC content of third synonymous codon

\begin{tabular}{|llllllll|}
\hline Species & Accession number & A3s(\%) & U3s(\%) & G3s(\%) & C3s(\%) & GC3s(\%) & GC(\%) \\
\hline Parasitus fimetorum & OK572962 & 42.78 & 45.62 & 13.66 & 24.66 & 29.90 & 32.20 \\
\hline Parasitus wangdunqingi & MK270528 & 40.69 & 50.64 & 18.84 & 16.20 & 25.50 & 29.80 \\
\hline
\end{tabular}

\section{Transfer RNA genes}

Using tRNAscan-SE [19] and ARWEN [20] programs, we were able to identify 20 tRNA genes in the mt genomes of $P$. fimetorum. Other than that, the other two mt tRNA genes of $P$. fimetorum ( $t r n P$ and $t r n S_{1}$ ) could only be found manually through sequence alignment and secondary structure comparison with genes previously identified in other species of Parasitiformes and Acariformes mite. It is common for animals to have a clover secondary structure, which comprises of four arms: the AA-arm, the D-arm, the AC arm, and the T-arm [26]. It has been calculated that the total length of $22 t R N A$ genes in the mitochondrial genome of $P$. fimetorum is $1390 \mathrm{bp}$ (only the sum of 22 tRNA genes is calculated, excluding gene overlap), that the A + T content is $72.6 \%$. All of the tRNAs in the secondary structure of $P$. fimetorum, with the exception of the serine $t R N A$ (anticodon GCU), can combine to form a typical secondary structure of clover. It is thought that serine tRNA was deficient in its $\mathrm{D}$-arm in practically all animals and was unable to create a stable secondary structure of clover, which is considered to be a characteristic feature of all chelicerate mitochondrial genomes, but this structure is not found in other tRNAs [10]. For the first time, the absence of the T-arm was discovered in the genes of nematode $t R N A s$, in which 20 out of 22 tRNAs lack the T-arm and the two tRNAs for serine (anticodons GCT and TGA) lack the D-arm [40]. Following this discovery, other tRNAs with similar structure have been found in the chelicerates, including the Acariformes [41], Araneae [42-44], Scorpiones [45-46], Thelyphonida [46], Pseudoscorpiones [47], Acanthocephala [48], Insecta [49], and Protura [50]. The secondary structures of 50 published mitochondrial genomes of Parasitiformes were observed, except for the loss of D-arm of serine $t R N A$, 44 species had atypical $t R N A$ structure, and the phenomenon of broken arm of $t R N A$ was fairly prevalent. Holothyrida has 1 species, Ixodida contains 30 species, and Mesostigmata includes 13 species with 22 tRNA secondary structures lacking D-arm or T-arm. No tRNAs of these species are deficient in both the D-and T-arms. The $t R N A$ breaking arm phenomena of Parasitiformes is less prevalent than Acariformes. For particular, in Acariformes, 19 out of the 22 mitochondrial $t R N A s$ of the Tetranychidae were found to be lacking either the D- or T-arm; in fact, in some species, the tRNAs for phenylalanine and glutamine were found to be deficient in both the D-and T-arm [24]. Demodicidae has $15 t R N A s$ that lack either the D-arm or the T-arm, as well as 5 tRNAs that lack both the D-arm and the T-arm [51]. Pyroglyphidae has 20 tRNAs with either D-arm or T-arm lacking [52], Trombiculidae have $18 t R N A$ without D-arm or T-arm [41], Acaridae and Psoroptidae have 21 tRNA lacking D-arm or Tarm [53], and Unionicolidae have 15 tRNA with missing arm [31-32].13 (trnD, $\operatorname{trn} G, \operatorname{trn} A, \operatorname{trn} R, \operatorname{trn} F, \operatorname{trn} H, \operatorname{trn} T, \operatorname{trn} S_{2}, \operatorname{trn} L_{2}, \operatorname{trn} V, \operatorname{trn} W$, $\operatorname{trn} C, \operatorname{trn} Y)$ of the $22 \operatorname{tRNA}$ genes found in $P$. fimetorum are within the average range $(62.0 \pm 1.3 \mathrm{bp})$ of $t R N A$ genes found in Parasitiformes [24]. The length of $8 \operatorname{tRNA}$ genes $\left(\operatorname{trn} K, \operatorname{trn} N, \operatorname{trn} E, \operatorname{trn} P, \operatorname{trn} L_{1}, \operatorname{trn} l, \operatorname{trn} Q, \operatorname{trn} M\right)$ is greater than the average size of Parasitiformes tRNA gene, with a range between $64 \sim 68 \mathrm{bp}$. Only one tRNA gene $\left(\operatorname{trn} S_{1}\right)$ was found to be shorter than the average length of the tRNA gene, and the loss of the D-arm can explain for only $59 \mathrm{bp}$ of the total length of the gene. In addition to the standard Waston-Crick pairings of $\mathrm{A}-\mathrm{U}$ and $\mathrm{G}-\mathrm{C}$, there are a number of mispairings, including $\mathrm{G}-\mathrm{U}, \mathrm{U}-\mathrm{U}$, and $\mathrm{A}-\mathrm{G}$, among others. $P$. fimetorum secondary structure for 22 tRNA genes consisting of 29 base mismatches and irregular pairings, of which 21 mismatches were G-U mismatches (Fig. 2). Only $15 t R N A$ genes ( $\operatorname{trn} A, \operatorname{trn} D, \operatorname{trn} G, \operatorname{trn} l, \operatorname{trn} K, \operatorname{trn} L_{2}, \operatorname{trn} M, \operatorname{trnN}, \operatorname{trn} P, \operatorname{trn} Q, \operatorname{trn} R, \operatorname{trn} S_{1}$, $\operatorname{trn} T$, trnV, trnW) have complete amino acid receptor arms (7bp), while the remaining $7 t R N A$ genes have base mismatches (1 2bp varies) in their amino acid receptor. Aside from that, $15 t R N A$ genes ( $\operatorname{trn} C, \operatorname{trn} D, \operatorname{trn} E, \operatorname{trn} G, \operatorname{trn} H, \operatorname{trn} l, t r n L_{1}, \operatorname{trnN}, \operatorname{trn} P, \operatorname{trnR}, \operatorname{trn} S_{2}, \operatorname{trn} T$, $\operatorname{trn} V, \operatorname{trn} W, \operatorname{trn} Y$ ) were able to generate a totally paired anticodon arm of 5bp, but the anticodon arms of the other 7 tRNA genes had a 1-2 base mismatch. Missmatch which is may be critical for preserving the integrity of the tRNAs secondary structure.

\section{Ribosomal RNA genes and Non-coding region}

There have been successful identifications of $r r n S$ gene (707bp) and $r r n L$ gene (1194bp), which are analogous to other mites, in the whole mitochondrial genome sequence of $P$. fimetorum. Genetic information about the position and structure of $r R N A$ genes is relatively conservative, and the pace of evolution is also conservative. As with other arthropods, two $r R N A$ genes are found on the $\mathrm{N}$-strand between $t r n L_{1}$ and the biggest non-coding region [54]. It was found that A+T content of $r r n S$ gene and $r r n L$ gene was

Page $12 / 20$ 
respectively $69.3 \%$ and $75.5 \%$. While $r r n S$ gene is situated in the region between $t r n L_{1}$ and $t r n V, r r n L$ gene is located in the region between $\operatorname{trn} V$ and non-coding region. There is a consistent pattern in the mitochondrial genome of arthropods, in which gene clusters such as rrnS-trnV-rrnL are organized.

The control region is the longest non-coding section in the mitochondrial genome, and it is responsible for the beginning of mitochondrial DNA replication and transcription. In most cases, this area contains nucleotides with an adenine (A) and thymine ( $T$ ) content greater than $85 \%$; therefore, the control region is sometimes referred to as the A+T-rich region [55]. P. fimetorum A+T content of control region were $77.6 \%$, and the similarity with the nucleotide sequence of $P$. wandunqingi control region was $68.1 \%$. It can be inferred that the two parasite mites evolved independently rather than co-evolved. According to Staffan and Anna (2000) [56], only independent evolution can result in a variation in the nucleotide sequence of a non-coding region, which ultimately results in the degeneration or deletion of a specific non-coding region. Non-coding region sections of the mitochondrial genome of the Parasitiformes differ in terms of their location, quantity, and length, and this is one of the primary reasons for the modest difference in overall length between mite genomes. With four control regions, Phytoseiulus persimilis (Physeiidae) is the species with the greatest number of control regions. Although it is the longest control area in the mites, the control area of Varroa destructor (Varroidae) is the longest (up to 2174bp), and the control area of Rhipicephalus simus (Ixodidae) is the shortest (only 309bp) (Table 2).

\section{Phylogenetic analysis based on cox1 gene sequences}

In recent years, a large number of researchers have used mixed gene segments for phylogenetic analysis, with the cox 1 gene being one of the most frequently used gene fragment. In terms of nucleotide and amino acid evolution, cox 1 is the slowest-evolving protein, making it a valuable marker for examining phylogenetic relationships at a higher level of classification [24]. In this study, the phylogenetic tree of cox 1 genes from 51 species of Parasitiformes was constructed using the ML method (maximum likelihood method) in MEGA-X software, Carcinoscorpius rotundicauda and Limulus polyphemus were used as outgroups (Fig. 3). The complete order of Parasitiforms phylogenetic relationship is (Ixodida + Holothyrida + Mesostigmata). The cladistic relationship of the phylogenetic tree showed that 51 species of Parasitiformes were divided into four clades, the first clade was composed of Ixodidae and Nuttalliellidae and formed a sister group with a node support rate of 76; the second clade was composed of Argasidae with the first evolutionary clade formed a sister group and a node support rate of 59; the third clade was composed of Allothyridar and the fourth clade was composed of 8 families of Mesostigmata. The overall node support rate of the phylogenetic tree in this study is strong, but the individual node support rate is poor, which may be owing to the limited sample size. Some families only collect samples from a single species, whereas other families have collected no samples at all. At the base node support rate of the constructed phylogenetic tree is really high. In general, the closer a node is to the tree root, the lower the node support rate will be for that node. This is due to the fact that this study only conducts a phylogenetic analysis on the cox 1 gene of a few parasitic mites belonging to the Parasitiformes. Our results suggested that nine families are monophyletic, which is in accordance with the result of Xue (2019) et al. [28].

\section{Conclusion}

As the big data era arrives, even more data will be used to explore animal genetic mitochondria. For the first time, the complete sequence of the $P$. fimetorum mitochondrial genome was determined and analyzed, and have retained the arrangement of arthropods hypothesized ancestor mitochondrial genome. Phylogeny of Parasitiformes mites was evaluated based on cox 1 gene. This research provides potentially a valuable source of information for understanding the phylogeny and evolution of Parasitiformes mites. Due to the obvious large geographical spread of mites, the relevant research has encountered myriad challenges. In addition, there are minor differences in the exterior morphological characteristics of some species, and there are still inconsistencies in the taxonomy and evolutionary position of some of the species studied. We should exploit the advantages of high-throughput sequencing technology in future research, increase the number of species and the number of mites used in research, as well as the number of molecular markers used in analysis, in order to analyze the taxonomic status and phylogenetic relationship of Parasitiformes more thoroughly and systematically.

\section{Abbreviations}


ul: Microliter; atp6 and atp8: Genes for ATP synthase subunits 6 and 8; bp: Base pair; cob: Gene for cytochrome b; $\operatorname{cox} 1, \operatorname{cox} 2$ and cox3: Genes for cytochrome c oxidase subunits 1, 2 and 3; DNA: Deoxyribonucleic acid; kb: Kilo base pair; min: Minute; ; mt: Mitochondrial; nad1, nad2, nad3, nad4, nad4L, nad5 and nad6: Mitochondrial genes for NADH dehydrogenase subunits 1-6 and 4 L; PCR: Polymerase chain reaction; RNA: Ribonucleic acid; rRNA: Ribosomal RNA; rrnS and rrnL: Genes for small and large subunits of ribosomal RNA; sec: Second; A: Adenine; T: Thymine; tRNA: Transfer RNA; rRNA: Ribosomal RNA; trnA or A: tRNA gene for alanine; trnC or C: tRNA gene for cysteine; trnD or D: tRNA gene for aspartic acid; trnE or E: tRNA gene for glutamic acid; trnF or F: tRNA gene for phenylalanine; trnG or G: tRNA gene for glycine; trnH or H: tRNA gene for histidine; trnl or I: tRNA gene for isoleucine; trnK or K: tRNA gene for lysine; trnL1 or L1: tRNA gene for leucine (anticodon NAG); trnL2 or L2: tRNA gene for leucine (anticodon YAA); trnM or M: tRNA gene for methionine; trnN or N: tRNA gene for asparagine; trnP or P: tRNA gene for proline; trnQ or Q: tRNA gene for glutamine; trnR or R: tRNA gene for arginine; trnS1 or S1: tRNA gene for serine (anticodon NCU); trnS2 or S2: tRNA gene for serine (anticodon NGA); trnT or T: tRNA gene for threonine; trnV or V: tRNA gene for valine; trnW or W: tRNA gene for tryptophan; trnY or Y: tRNA gene for tyrosine; U: Uracil.

\section{Declarations}

\section{Acknowledgements}

We thank JiaNing Sun for assistance with an initial phylogenetic tree analysis.

\section{Funding}

We acknowledge funding support from the National Natural Science Foundation of China (No. 32060143 to WGD). The funding agencies had no roles in the design of the study and collection, analysis, and interpretation of data and in writing the manuscript.

\section{Availability of data and materials}

The nucleotide sequence of the mitochondrial genome of the Parasitus fimetorum, has been deposited in GenBank (accession number OK572962) and will be released publicly once this manuscript is accepted for publication.

\section{Authors' contributions}

HJY, WGD and TC designed the research. HJY performed the research. WGD contributed reagents and materials. HJY and WGD analysed the data. HJY and WGD wrote the manuscript. All authors have read and approved the final manuscript.

\section{Ethics approval and consent to participate}

Capture of Apodemus chevrieri was approved by health authorities in Yunnan Province, China. Animal capture protocols and procedures were approved by the animal ethics committees at Dali University (approval \# DLDX-20100421-001). All collection methods were carried out in accordance with the approved guidelines and regulations.

\section{Consent for publication}

Not applicable

\section{Competing interests}

The authors declare that they have no competing interests to declare.

\section{Author details}

Hui-Juan Yang, Hunan, China. Institute of Pathogens and Vectors, Dali University, and the Key Laboratory for Preventing and Controlling Plague in Yunnan Province, Dali 671000, China

Ting Chen, Yunnan, China. Institute of Pathogens and Vectors, Dali University, and the Key Laboratory for Preventing and Controlling Plague in Yunnan Province, Dali 671000, China

Page $14 / 20$ 
Wen-Ge Dong, Yunnan, China. Institute of Pathogens and Vectors, Dali University, and the Key Laboratory for Preventing and Controlling Plague in Yunnan Province, Dali 671000, China

\section{References}

1. Frederic B, Ashley P.G. D, Hans K, DE MORAES, Gilberto J. D M, David Evans W. Superorder Parasitiformes Reuter, 1909. In: Zhang, Z.-Q. (Ed.) Animal biodiversity: An outline of higher-level classification and survey of taxonomic richness. Zootaxa. 2011;1:123-128.

2. Negm M.W, Gotho T. Mites of the family Parasitidae Oudemans, 1901 (Acari: Mesostigmata) from Japan: a new species of Vulgarogamasus Tichomirov, 1969, and a key to Japanese species. Zootaxa. 2018;3:379-389.

3. Hany M H. Parasitus fimetorum and Macrocheles muscaedomesticae (Acarina: Parasitidae, Macrochelidae) as Natural Predators of the Root Knot Nematode, Meloidogyne javanica Treub. Egypt J Biol Pest Co. 2020;30:265-271.

4. Hrúzová K, Fenda P. First record of Parasitus americanus (Berlese, 1905) and Cornigamasus ocliferius Skorupski \& Witaliński, 1997 (Acari: Mesostigmata: Parasitidae) from Slovakia. Check List. 2017;13:239-243.

5. Yao MY, Guo JJ, Yi TC, Jin DC. Description of Cornigamasus allotritosternus sp. nov. (Mesostigmata: Parasitidae) from China, with an emphasis on the ontogenetic development of setae. Zootaxa. 2020;4821:462-486.

6. Blanckman SW. Experimental evidence that the mite Poecilochirus davydovae (Mesostigmata: Parasitidae) eats the eggs of its beetle host. J ZOOL. 1997;242:63-67.

7. Juha M. Biological Diversity and Function in Soils. Ecoscience. 2006;13:557-567.

8. Bardgett, R D., van der Putten W H. Belowground biodiversity and ecosystem functioning. Nature. 2014;515:505-511.

9. Boore J L. Animal mitochondrial genomes. Nucleic Acids Res. 1999;27:1767-1780.

10. Wolstenholme D R. Animal mitochondrial DNA: structure and evolution. International Review of Cytology. 1992;141:173-216.

11. Masta, S E. Mitochondrial sequence evolution in spiders: intraspecific variation in tRNAs lacking the TPsiC Arm. Mol Biol Evol. 2000;17:1091-1100.

12. Shao R, Barker S C. Mitochondrial genomes of parasitic arthropods: implications for studies of population genetics and evolution. Parasitology. 2007;134:153-167.

13. Zhou ZJ, Zhao L, Liu N, Guo HF, Guan B, Di JX, Shi FM. Towards a higher-level Ensifera phylogeny inferred from mitogenome sequences. Mol Phylogenet Evol. 2017;108:22-33.

14. Miya M, Nishida M. Use of Mitogenomic Information in Teleostean Molecular Phylogenetics: A Tree-Based Exploration under the Maximum-Parsimony Optimality Criterion. Mol Phylogenet Evol. 2000;17:437-455.

15. Ma C, Li J K. Comparative analysis of mitochondrial genomes of the superfamily Grylloidea (Insecta, Orthoptera) reveals phylogenetic distribution of gene rearrangements. Int J Biol Macromol. 2018;120:1048-1054.

16. Dermauw W, Leeuwen T V, Vanholme B, Tirry L. The complete mitochondrial genome of the house dust mite Dermatophagoides pteronyssinus (Trouessart): a novel gene arrangement among arthropods. BMC. 2009;10:107-126.

17. Dabert J., Ehrnsberger R., Dabert M. Glaucalges tytonis sp. n. (Analgoidea, Xolalgidae) from the barn owl Tyto alba (Strigiformes, Tytonidae): Compiling morphology with DNA barcode data for taxon descriptions in mites (Acari). Zootaxa. 2008;1719:41-52.

18. Kearse M, Moir R, Wilson A, Stones-Havas S, Cheung M, Sturrock S, et al. Geneious Basic: An integrated and extendable desktop software platform for the organization and analysis of sequence data. Bioinformatics. 2012;28:1647-1649.

19. Schattner P., Brooks A. N., Lowe, T. M. The tRNAscan- SE, snoscan and snoGPS web servers for the detection of tRNAs and snoRNAs. Nucleic Acids Research. 2005;33:686-689.

20. Laslett, D., Canback B. ARWEN: A program to detect tRNA genes in metazoan mitochondrial nucleotide sequences. Bioinformatics. 2008;24:172-175.

21. Benson DA, Cavanaugh M, Clark K, Karsch-Mizrachi I, Lipman DJ, Ostell J, et al. GenBank. Nucleic Acids Res. 2013;41:36-42.

22. Sudhir K, Glen S, Michael L, Christina K, Koichiro T. MEGA X: Molecular Evolutionary Genetics Analysis across Computing Platforms. Mol Biol Evol. 2018;35:1547-1549.

Page $15 / 20$ 
23. Silva G.G., Dutilh B.E., Matthews T.D., Elkins K., Schmieder R., Dinsdale E.A., et al. Combining de novo and reference-guided assembly with scaffold builder. Source Code for Biology and Medicine. 2013;23:609-613.

24. Yuan ML, Wei DD, Wang BJ, Wei SD, Wang JJ. The complete mitochondrial genome of the citrus red mite Panonychus citri (Acari: Tetranychidae): high genome rearrangement and extremely truncated tRNAs. BMC. 2010;11:597-612.

25. Burger TD, Shao RF, Labruna MB, Barker S. Molecular phylogeny of soft ticks (Ixodida: Argasidae) inferred from mitochondfial genome and nuclear rRNA sequences. Ticks Tick-Borne Dis. 2014;5:195-207.

26. Shao RF, Aoki Y, Mitani H, Tabuchi N, Barker S. C., Fukunaga M. The mitochondrial genomes of soft ticks have an arrangement of genes that has remained unchanged for over 400 million years. Insect Mol Biol. 2004;13:219-224.

27. Xue XF, Guo GF, Dong Y, Hong XH, Shao RF. Mitochondrial genome evolution and tRNA truncation in Acariformes mites: new evidence from eriophyoid mites. Scientific Reports. 2016;6:93-113.

28. Li WN, Shao R, Zhang Q, Deng W, Xue X-F. Mitochondrial genome reorganization characterizes various lineages of mesostigmatid mites (Acari: Parasitiformes). Zool Scr. 2019;0:1-11.

29. Burger, T D, Shao, RF \& Barker, S C. Phylogenetic analysis of the mitochondrial genomes and nuclear rRNA genes of ticks reveals a deep phylogenetic structure within the genus Haemaphysalis and further elucidates the polyphyly of the genus Amblyomma with respect to Amblyomma sphenodonti and Amblyomma elaphense. Ticks Tick-Borne Dis. 2013;4:265-274.

30. Navajas M., Le Conte Y., Solignac M., Cros-Arteil S., Cornuet J.M. The complete sequence of the mitochondrial genome of the honeybee ectoparasite mite Varroa destructor (Acari: Mesostigmata). Mol Biol Evol. 2002;19:2313-2317.

31. Edwards D. D., Jackson L. E., Johnson A. J., Ernsting, B. R. Mitochondrial genome sequence of Unionicola parkeri (Acari: Trombidiformes: Unionicolidae): molecular synapomorphies between closely-related Unionicola gill mites. Exp. Appl Acarol. 2011;54:105-117.

32. Ernsting B. R., Edwards D. D., Aldred K. J., Fites J. S., Neff, C. R. Mitochondrial genome sequence of Unionicola foili (Acari:Unionicolidae): a unique gene order with implications for phylogenetic inference. Exp Appl Acarol. 2009;49:305-316.

33. Sun E T, Li C P, Nie L W, Jiang Y X. The complete mitochondrial genome of the brown leg mite, Aleuroglyphus ovatus (Acari: Sarcoptiformes): evaluation of largest non-coding region and unique tRNAs. Exp Appl Acarol. 2014;64:141-157.

34. Ruth H, Dmitri A. P. Selection on Codon Bias. Annu Rev Genet. 2008;42:287-299.

35. Plotkin J B., Kudla G. Synonymous but not the same: the causes and consequences of codon bias. Nat Rev Genet. 2011;12:3242.

36. Avise J C. Phylogeography: the history and formation of species. London: Harvard University Press; 2000.

37. Kimura M. Possibility of Extensive Neutral Evolution under Stabilizing Selection with Special Reference to Nonrandom Usage of Synonymous Codons. P Natl Acad Sci USA. 1981;78:5773-5777.

38. Chen S L., Lee Q, Hottes A K., Shapiro L, McAdams H H. Codon Usage between Genomes Is Constrained by Genome-Wide Mutational Processes. P Natl Acad Sci USA. 2004;101:3780-3485.

39. Knight R D, Freeland S J, Landweber L F. A simple model based on mutation and selection explains trends in codon and amino-acid usage and GC composition within and across genomes. Genome Biol. 2001;2:35-47.

40. Wolstenholme D R, Macfarlane J L, Okimoto R, Clary D O, Wahleithner J A. Bizarre transfer RNAs inferred from DNA sequences of mitochondrial genomes of nematode worms. Proc Natl Acad Sci USA. 1987;84:1324-1328

41. Shao R F, Mitani H, Barker S C, Takahashi M, Fukunaga M. Novel Mitochondrial Gene Content and Gene Arrangement Indicate Illegitimate Inter-mtDNA Recombination in the Chigger Mite, Leptotrombidium pallidum. J Mol Evol. 2005;60:764-773.

42. Masta S. E., Boore J. L. The complete mitochondrial genome sequence of the spider Habronattus oregonensis reveals rearranged and extremely truncated tRNAs. Mol Biol Evol. 2004;21:893-902.

43. Qiu Y., Song D., Zhou K., Sun H.The mitochondrial sequences of Heptathela hangzhouensis and Ornithoctonus huwena reveal unique gene arrangements and atypical tRNAs. Mol Evol. 2005;60:57-71.

44. Liu M., Zhang Z., Peng, Z. The mitochondrial genome of the water spider Argyroneta aquatica (Araneae: Cybaeidae). Zool Scr. 2014;44:179-190.

45. Dávila S., Piñero D., Bustos P., Cevallos M. A., Dávila G. The mitochondrial genome sequence of the scorpion Centruroides limpidus (Karsch 1879) (Chelicerata; Arachnida). Gene. 2005;360:92-102. 
46. Masta S. E., Boore J. L. Parallel evolution of truncated transfer RNA genes in arachnid mitochondrial genomes. Mol Biol Evol. 2008;25:949-959.

47. Ovchinnikov, S., Masta S. E. Pseudoscorpion mitochondria show rearranged genes and genome-wide reductions of RNA gene sizes and inferred structures, yet typical nucleotide composition bias. BMC Evol Biol. 2012;12:31-49.

48. Steinauer M. L., Nickol B. B., Broughton R., Ortí, G. First sequenced mitochondrial genome from the phylum Acanthocephala (Leptorhynchoides thecatus) and its phylogenetic position within Metazoa. Mol Evol. 2005;60:706-715.

49. Beckenbach, A. T., Joy, J. B. Evolution of the mitochondrial genomes of gall midges (Diptera: Cecidomyiidae): rearrangement and severe truncation of tRNA genes. Genome Biol Evol. 2009;1:278-287.

50. Chen W. J., Bu Y, Carapelli A, Dallai R, Li S, Yin WY, Luan YX. The mitochondrial genome of Sinentomon erythranum (Arthropoda: Hexapoda: Protura): an example of highly divergent evolution. BMC Evol Biol. 2011;11:246-257.

51. Palopoli M F, Minot S, Pei D, Satterly A, Endrizzi, J. Complete mitochondrial genomes of the human follicle mites Demodex brevis and $\mathrm{D}$. folliculorum: novel gene arrangement, tnmcated tRNA genes, and ancient divergence between species. BMC Genomics. 2014;15:1-15.

52. Dermauw W, Leeuwen TV, Vanholme B, Tirry L. The complete mitochondrial genome of the house dust mite Dermatophagoides pteronyssinus (Trouessart): a novel genearrangement among arthropods. BMC Genomics. 2009;10:107126.

53. Sun E T, Li C P, Nie L W, Jiang Y X. The complete mitochondrial genome of the brown leg mite, Aleuroglyphus ovatus (Acarr: Sarcoptiformes):evaluation of largest non-coding region and unique tRNAs. Exp Appl Acarol. 2014;64:141-157.

54. Zhang D X, Hewitt G M. Insect mitochondrial control region: a review of its structure, evolution and usefulness in evolutionary studies. Biochem Syst Ecol. 1997;25:99-120.

55. Taanman J W . The mitochondrial genome: structure, transcription, translation and replication. BbaBiomembranes. 1999;1410:103-123.

56. Staffan B, Anna H. Mitochondrial Genomic Rearrangements in Songbirds. Mol Bio Evol. 2000;17:107-113.

\section{Supplementary Information}

Supplementary Information is not available with this version.

\section{Figures}




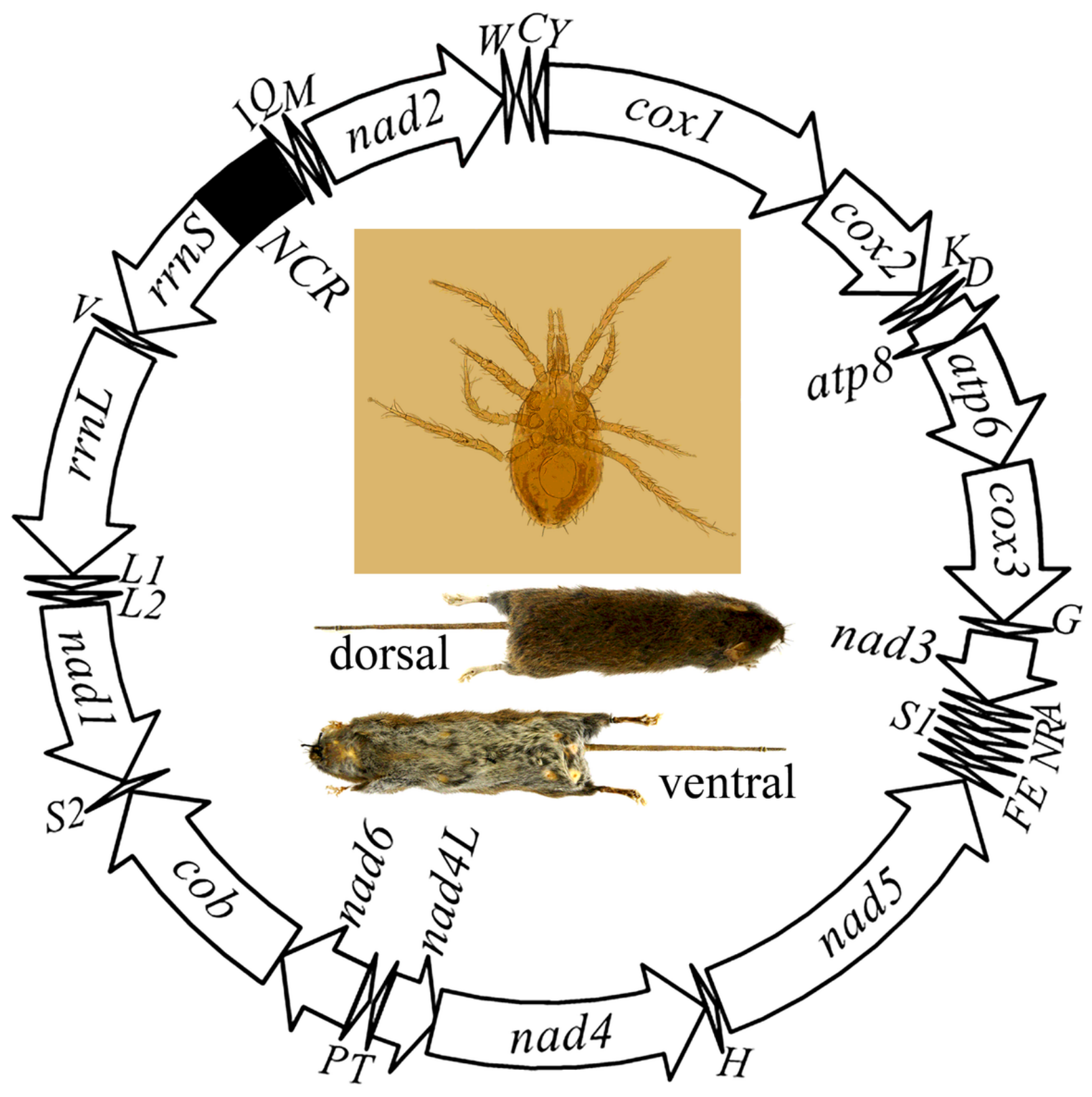

Figure 1

The mitochondrial $(\mathrm{mt})$ genomes of P. fimetorum. The direction of the arrow represents the direction of transcription. Abbreviations for gene names. NCR refers to non-coding region. 22 tRNA genes are designated with one letter amino acid codes. 

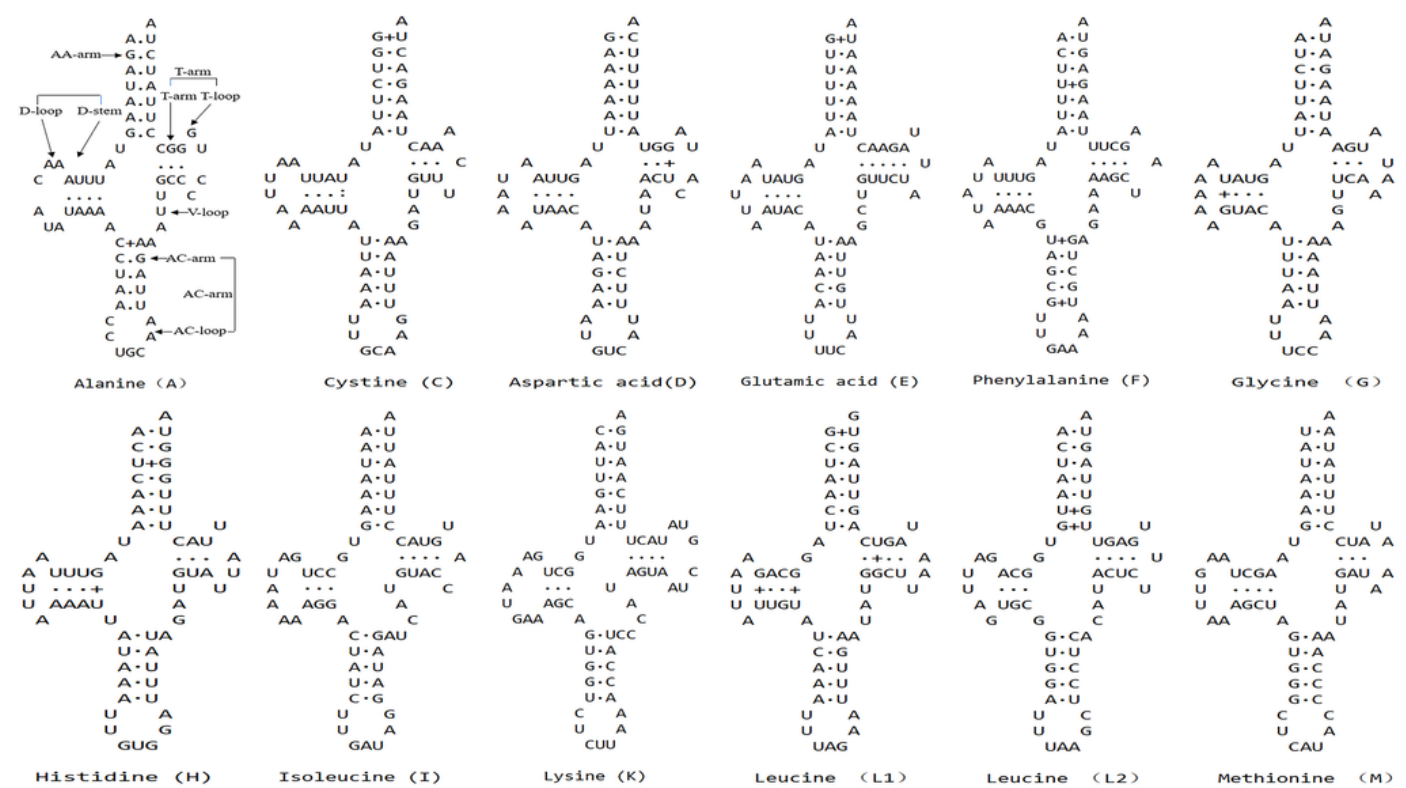

Isoleucine (I)
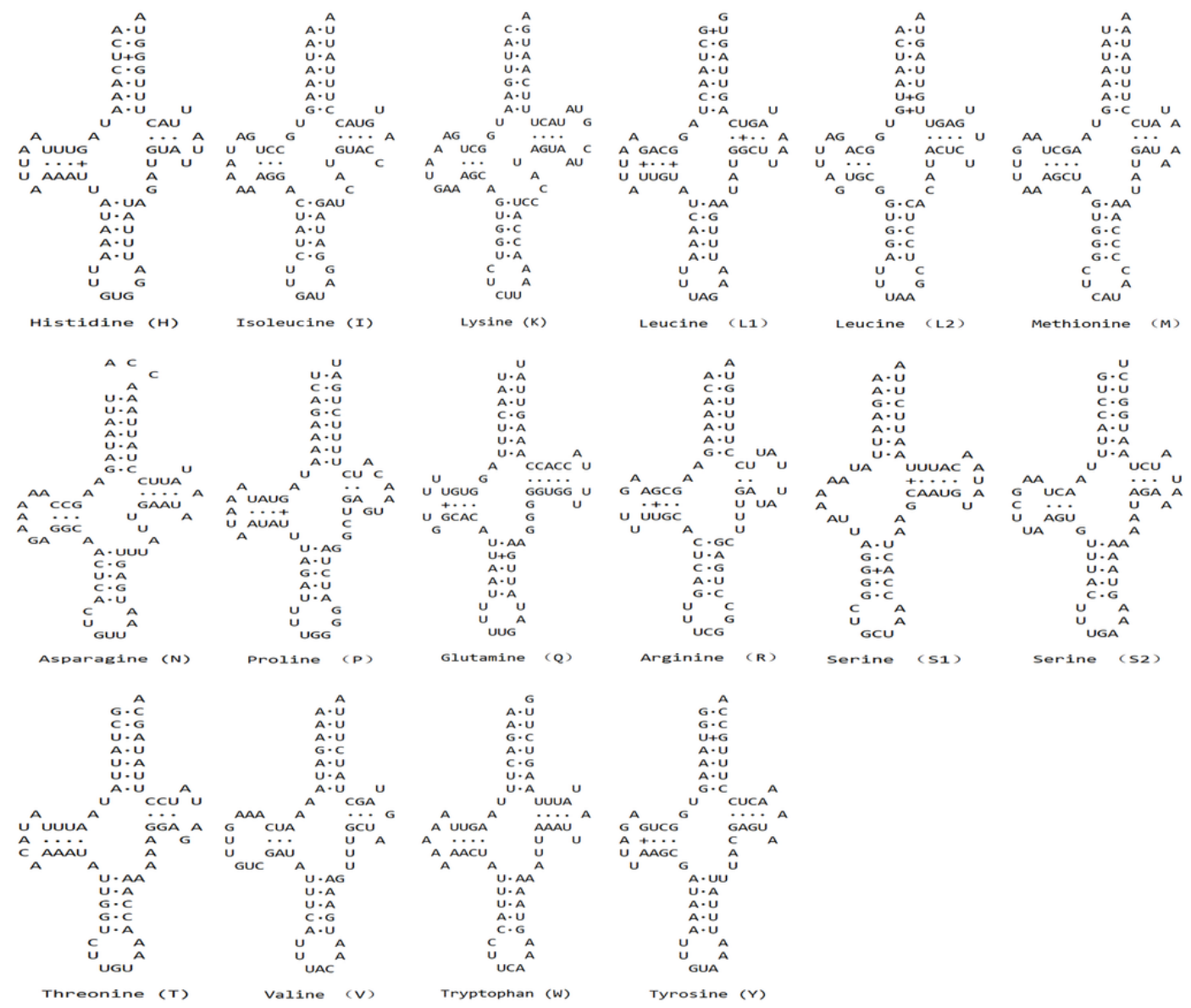

Figure 2

Inferred secondary structures of the mitochondrial tRNAs of P. fimetorum. 


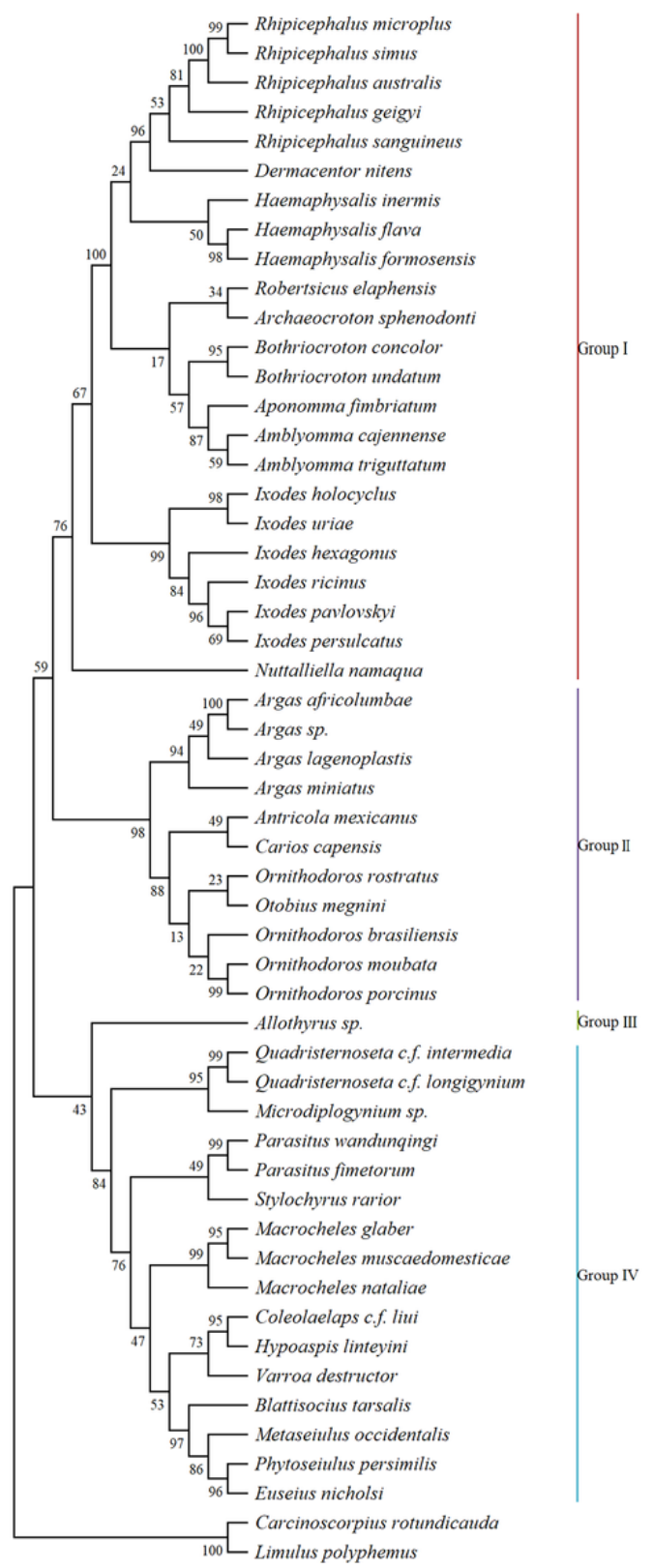

Figure 3

Phylogenetic relationships of 51 species of parasitic mites based on mitochondrial genomes. The phylogenetic tree was constructed based on nucleotide sequences of cox 1 gene using maximum likelihood. The numbers at the nodes are bootstrap values. The GenBank accession numbers of the 51 mitochondrial genome sequences are listed in Table 2.

\section{Supplementary Files}

This is a list of supplementary files associated with this preprint. Click to download.

- GraphicalAbstract.tif 